\title{
Oral history w badaniu najnowszej historii politycznej - garść refleksji (na dwóch przykładach)
}

Punktem wyjścia do niniejszych rozważań stały się moje dwa, zupełnie różne doświadczenia z wykorzystaniem źródeł ustnych. Pierwsze doświadczenie to łącznie kilkadziesiąt godzin nagrań relacji kilkunastu opozycjonistów, członków podziemnego Niezależnego Zrzeszenia Studentów na Uniwersytecie Warszawskim w latach 1982-1989. Wywiady przeprowadziłem wraz z Robertem Spałkiem na przestrzeni kilku miesięcy w latach 2008-2009. Nasza współpraca zaowocowała książką, stanowiącą pewnego rodzaju kolaż wypowiedzi świadków historii ${ }^{2}$.

Drugie doświadczenie to niespodziewana spowiedź człowieka z drugiej strony barykady: Edmunda Łebka, funkcjonariusza UB z lat 4o. XX w., który miał na sumieniu ludzkie życie. Historię tego zdarzenia opisałem w innym miejscu - tutaj więc ograniczę się do kilku informacji³. Impulsem do nagra-

1 https://orcid.org/oooo-ooo1-5627-8325.

2 P. Pleskot, R. Spałek, Pokolenie 82-9o. Niezależne Zrzeszenie Studentów na Uniwersytecie Warszawskim we wspomnieniach (1982-199o), Warszawa 2011.

$3 \quad$ P. Pleskot, W butach esbeka. Kilka refleksji na temat konfliktu emic-ethic w badaniach nad aparatem bezpieczeństwa PRL, [w:] Aparat bezpieczeństwa $w$ perspektywie antropologii władzy $i$ antropologii organizacji, red. J. Syrnyk, Wrocław 2020 (w przygotowaniu). 
nia relacji był artykuł, który opublikowałem w „Przeglądzie Archiwalnym” w 2009 r. $^{4}$ Było to typowe case study, opisujące na przykładzie Łebka problem bezkarności funkcjonariuszy UB i powszechną praktykę tuszowania przestępstw popełnianych przez pracowników MBP. Pokrótce - pochodzący z Francji Łebek, młodszy referent kontrwywiadowczego Departamentu I MBP, wieczorem 26 sierpnia 1946 r., zastrzelił na warszawskiej ulicy agenta „Freda”, z którym czasowo mieszkał, uciekł z miejsca zbrodni i, mimo szybkiego złapania, uniknął kary, a dzięki wstawiennictwu zwierzchników rozpoczął pracę w MO.

Kilka lat po napisaniu tego tekstu, zupełnie niespodziewanie, na mój e-mail wpłynęła wiadomość od krewnych Edmunda Łebka, którzy zapoznali się $\mathrm{z}$ artykułem i postanowili zareagować ${ }^{5}$ Ku mojemu zdumieniu okazało się, że bohater artykułu wciąż żył (miał już ponad 9o lat), czego wcześniej nie udało mi się ustalić. Rodzina była wstrząśnięta informacjami, które ujawniłem w tekście. Do tej pory bliscy Łebka nie mieli pojęcia o tragicznych wydarzeniach z sierpnia $1946 \mathrm{r}$. i zastanawiali się, czy powiedzieć mu o znalezionym artykule. Ostatecznie postanowili nie ukrywać przed Edmundem dokonanego odkrycia, a mnie zaproponowali spotkanie w rodzinnym domu, podczas którego Łebek miał przybliżyć okoliczności zdarzeń sprzed 70 lat. Okazało się, że sędziwy już bohater tekstu to sympatyczny, gadatliwy człowiek, o świetnej, szczegółowej, choć nieco chaotycznej pamięci.

Poniżej nie zamierzam opisywać losów warszawskich opozycjonistów ani krętych ścieżek życia funkcjonariuszy komunistycznego aparatu represji. Chodzi o wykorzystanie tych przykładów do podzielenia się kilkoma refleksjami związanymi z zastosowaniem oral history w badaniach nad najnowszymi dziejami politycznymi Polski. Zderzenie konkretnej pracy badawczej z teorią i metodologią historii mówionej pozwala dostrzec korzyści i niebezpieczeństwa związane z wykorzystywaniem tego typu źródeł.

\section{Kontekst chronologiczny}

Stosowanie źródeł ustnych we współczesnej historiografii dziejów najnowszych wydaje się koniecznością. Badacze na ogół rozumieją, jak wielkie bogactwo kryje w sobie to podejście metodologiczne. W końcu źródłem

$4 \quad$ Zbrodnia i kara w MBP. Sprawa Edmunda Łebka, „Przegląd Archiwalny”, t. 2 (2009), s. 325-334.

5 E-mail wnuka Edmunda Łebka do autora, 26 IV 2016 r. 
ustnym jest wszystko to, co z różnych powodów nie zostało spisane; pozwala na odkrycie fragmentów historii nie uwzględnionej w oficjalnych dokumentach i pominiętej przez klasycznych archiwistów. Prawidłowość ta nie dotyczy jedynie wymiaru społeczno-socjologicznego i przypominania o grupach społecznych pomijanych przez tradycyjną historiografię, lecz również tyczy się najnowszej historii politycznej, której meandry i kulisy często są nieobecne w tradycyjnych śladach historii ${ }^{6}$.

Jak wiadomo, historia mówiona jako jedna z nauk historycznych narodziła się w pierwszej połowie XX w., i rozwinęła w tym czasie przede wszystkim w USA. Inne kraje zachodnie, jak np. Francja, zaczęły na większą skalę stosować źródła ustne i promować hasło histoire immediate czy też „źródeł czasu teraźniejszego” dopiero w latach 7o. XX w. W przypadku Polski było jeszcze trudniej. Uwarunkowania polityczne systemu komunistycznego implikowały m.in. ucieczkę historyków w dawniejsze epoki, tendencję do unikania drażliwych tematów czy autocenzurę̧.

Pewien dystans historiografii do oral history tłumaczy zapewne fakt, że archetypów historii mówionej należy szukać przede wszystkim w pracach dziewiętnastowiecznych folklorystów, lingwistów i etnologów, a także w Durkheimowskiej socjologii fin de siècle'u - a nie samych historyków. Na gruncie amerykańskim metodę tę po raz pierwszy rozwinęła chicagowska szkoła socjologii w okresie 1910-1935. Reprezentanci tego środowiska, jak Robert E. Park czy Ernest W. Burgess, wykorzystywali świadectwa ustne badanych przez siebie osób (m.in. emigrantów), łącząc warsztat etnologa i socjologa ${ }^{8}$.

W 1930 r. władze federalne zleciły szeroko zakrojone badania, mające na celu zebranie wspomnień byłych niewolników9. To pierwszy przykład wielkiego przedsięwzięcia historii mówionej. W 1942 r. pojęcie oral history zyskało nowy wymiar i nową pozycję: w tym roku sam prezydent Franklin D. Roosevelt

6 Zgodnie z klasycznym ujęciem oral history, zob.: C. Ginzburg, C. Poni, La micro-histoire, „Le Débat. Histoire, politique, société”, t. 17 (1981), s. 133-136.

7 Więcej na ten temat zob. m.in. w: P. Pleskot, Intelektualni sasiedzi. Kontakty polskich historyków z francuskim środowiskiem „Annales” w latach 1945-1989, Warszawa 2010 .

$8 \quad$ Zob. np.: R.E. Park, E.W. Burgess, Introduction to the Science of Sociology, Chicago 1921; R.E. Park, E.W. Burgess, R. McKenzie, The City, Chicago 1925.

9 Ph. Joutard, Orale (histoire), [w:] Dictionnaire des sciences historiques, red. A. Burguière, Paris 1986, s. 495. 
wyraził życzenie zmobilizowania badaczy do zbierania świadectw uczestników wojny i zachowania ich wspomnień. Co ciekawe, zajęli się tym przede wszystkim dziennikarze. W tym okresie nie wykorzystywano jeszcze w USA mikrofonu do pracy historycznej. Wyniki przedsięwzięcia były imponujące: w ciągu kilku lat zebrano ponad 10 tys. świadectw uczestników wojny ${ }^{10}$.

Pod koniec lat 40. XX w. amerykański dziennikarz (znowu niehistoryk) Allan Nevins rozpoczął projekt zakładający zbadanie bliskiej przeszłości przez odpytywanie przedstawicieli elit, decydentów przeszłych wydarzeń. Nevins założył ponadto Oral History Research Office na Uniwersytecie Columbia, które do dziś pozostaje jedną z największych tego typu instytucji na świecie ${ }^{11}$. Warto dodać, że u progu XXI w. niemal każdy fakultet historyczny a merykańskiej uczelni posiada zakład/katedrę historii mówionej. Rzecz to jeszcze nie do pomyślenia w Polsce.

Tymczasem już w latach 50. i 60. XX w. źródła ustne zaczęły być powszechnie wykorzystywane przez anglosaskich historyków, często jednak z podtekstem ideologicznym. Lewicowa i kontestatorska szkoła Paula R. Thompsona, związana z rewolucją obyczajową lat 6o. XX w., postawiła sobie za cel badanie środowisk zapomnianych przez oficjalny nurt historyczny - np. mniejszości etnicznych i seksualnych - wszystkich, o których do tej pory nie pisano, a teraz chciano wysłuchać i uzupełnić dotychczas zebrane źródła historyczne o ich świadectwa ${ }^{12}$. W tym okresie bardzo popularne stały się również badania nad pamięcią Shoah, często prowadzone na gigantyczną skalę. W latach 90. XX w. projekt przeprowadzenia tysięcy wywiadów z ofiarami Holocaustu nadzorował sam Steven Spielberg ${ }^{13}$.

Pewien opór historyków reprezentujących tradycyjną historiografię przed wykorzystywaniem źródeł ustnych wynikał również z długotrwałego i głęboko zakorzenionego w warsztacie historyka założenia, że obiektywnie da się badać tylko to, co bezpowrotnie minęło. Dopóki więc żyją świadkowie jakichś wydarzeń, dopóty nie można ich naukowo analizować. Ogólne

10 Część relacji jest dostępna online, m.in. na stronach Biblioteki Kongresu; zob.: Veterans History Project, www.loc.gov (dostęp: 17 IV 2020 r.).

11 W zbiorach tego uniwersytetu można znaleźć m.in. transkrypcje licznych wywiadów przeprowadzonych przez Nevinsa.

12 Zob.: P.R. Thompson, Voice of the Past: Oral History, New York 1978.

13 Zob.: Visual History Archive, University of Southern California Shoah Foundation, https://sfi.usc.edu/vha/about (dostęp: 17 IV 2020 r.). 
przezwyciężenie tego dogmatu w sposób niezależny od ideologii nastąpiło w Europie Zachodniej w połowie XX w., a w krajach byłego bloku wschodniego dopiero w ostatnich trzydziestu latach.

Niewiele wcześniej, bo mniej więcej od siódmej dekady XX w. pojawił się (równolegle do ofensywy szeroko rozumianego postmodernizmu) co najmniej jeden katalizator rozwoju historii mówionej: fenomen określany przez historyków francuskich jako retour de mémoire ${ }^{14}$. Powszechnym społecznym zjawiskiem stała się potrzeba upamiętniania przeszłości, rekonstrukcji korzeni indywidualnych, rodzinnych i przeszłości najbliższych okolic. Jak zauważa François Hartog, „pamięć poczęła wypierać historię” ${ }^{15}$. Rekonstrukcji i upamiętnieniu (commémoration) przeszłości miało służyć zbieranie świadectw świadków historii. Dodajmy dla równowagi, że w tym kontekście pojawiły się również głosy krytyczne, podważające wiarygodność tego typu historiografii (np. w pracach Gérarda Noiriela ${ }^{16}$ ).

Po upadku komunizmu również w krajach Europy Środkowo-Wschodniej nastąpił przyspieszony rozwój historii mówionej i jej nowych kierunków, np. egohistorii ${ }^{17}$, motywowany m.in. chęcią odkłamania oficjalnej wykładni dziejów, obowiązującej w PRL. Do prekursorów tego gatunku należy zaliczyć Krystynę Kersten i Tomasza Szarotę ${ }^{18}$. Obecnie wykorzystywanie źródeł ustnych rozpowszechniło się nie tylko w środowisku naukowców, ale i w całym społeczeństwie. Równolegle do źródeł wywołanych sięgają najróżniejsze instytucje badawcze: od tradycyjnych instytutów uniwersyteckich i placówek PAN, po utworzone stosunkowo niedawno organizacje i inicjatywy, jak Instytut Pamięci Narodowej czy różne archiwa historii

14 Egohistoria to nurt w oral history, w którym zawodowy historyk analizuje własną pamięć czy wspomnienia lub też pamięć/relacje innych historyków, zob.: Les lieux de mémoire, red. P. Nora, t. 1-7, Paris 1984-1992; F. Hartog, Régimes d'historicité. Présentisme et expériences du temps, Paris 2003; Ph. Joutard, Orale (histoire)..., s. 496.

15 F. Hartog, op. cit., s. 113-162.

16 Zob.: G. Noiriel, Qu'est-ce que l'histoire contemporaine?, Paris 1998; idem, Sur la crise de l'histoire, Paris 1996; idem, Penser avec, penser contre. Itinéraire d'un historien, Paris 2003.

17 Zob.: Essais d'ego-histoire, red. P. Nora, Paris 1987.

18 Zob.: Wieś polska 1939-1948. Materiaty konkursowe, oprac. K. Kersten, T. Szarota, Warszawa 1967-1971. 

Warszawskiego i Ośrodek „Brama Grodzka - Teatr NN” w Lublinie, oraz periodyki na czele z „Wrocławskim Rocznikiem Historii Mówionej”19.

\section{Źródła pisane vs. wywołane}

Interpretacja świadectw ustnych wiąże się z zastosowaniem szczególnej metody badawczej. Problem sprawia znaczenie stojące za określeniem: świadek. Z prawniczego punktu widzenia świadek daje świadectwo, czyli przekazuje prawdę o danym wydarzeniu ${ }^{20}$. Jednak w znaczeniu empirycznym świadek donosi o czymś, co się zdarzyło w przeszłości - „byłem tam”; konstruuje opowiadanie, narrację - nie daje świadectwa sensu stricto, lecz opowiada. Do słuchającego historyka należy natomiast poddanie uzyskanego materiału analizie. W pewnej mierze to właśnie historyk tworzy świadectwo, a na pewno czynnie uczestniczy w tworzeniu źródła ${ }^{21}$.

Zjawisko to implikuje niezwykłą sytuację warsztatową: historyk wraz ze świadkiem historii poniekąd fabrykują źródło historyczne i pośrednio tworzą obraz przeszłości. W przypadku innego typu źródeł taką ingerencję badawczą można by zaliczyć do najcięższych grzechów warsztatowych. Na niezwykły charakter tego zjawiska badawczego zwrócili uwagę François Bédarida $^{22}$ i Pierre Bourdieu ${ }^{23}$. Czynna postawa historyka w tworzeniu

19 Na gruncie polskim po 1989 r. metodologię oral history pogłębiali i upowszechniali m.in. Marta Kurkowska-Budzan (zob. m.in. eadem, Antykomunistyczne podziemie zbrojne na Białostocczyźnie. Analiza współczesnej symbolizacji przeszłości, Kraków 2009; eadem, Historia zwyktych ludzi. Wspótczesna angielska historiografia dziejów społecznych, Kraków 2003), Krzysztof Pomian (idem, Historia. Nauka wobec pamięci, Lublin 2006) czy Agata Stolarz (eadem, Dzielenie się pamięcią. Praktyka i teoria historii mówionej, Lublin 2016).

20 W tym kontekście pojęcie prawdy wywodzi się z tradycji arystotelesowskiej i klasycznej definicji zgodności sądów z rzeczywistością. Ujęcie to zakłada obiektywne istnienie rzeczywistości, co podaje w wątpliwość szeroko rozumiany nurt idealistyczny w filozofii.

21 Zob.: Ph. Joutard, Historiens, à vos micros! Le document oral, une nouvelle source pour l'histoire, „L'Histoire”, t. 12 (1979), s. 106-120.

22 Zob.: F. Bédarida, Le mémoire contre l'histoire, „Esprit”, nr 7 (1993); idem, L'historien, régisseur du temps? Savoir et responsabilité, „Revue historique”, nr 605 (1/1998).

23 P. Bourdieu, Sur les rapports entre la sociologie et l'histoire en Allemagne et en France. Entretien avec Lutz Raphael, "Actes de la recherche en Sciences Sociales”, nr 106-107 (1995), s. 117-119. 
materiału historycznego odróżnia również źródła ustne od archiwaliów audiowizualnych. W przypadku tych ostatnich badacz jedynie w bierny i tradycyjny sposób korzysta z udostępnionych nagrań.

To współtworzenie zostaje zderzone z klasyczną krytyką źródeł. Przeprowadzając krytykę relacji historii mówionej, historyk znajduje się w schizofrenicznej sytuacji: z jednej strony najpierw współtworzy materiał badawczy (co w odniesieniu do tradycyjnych źródeł jest całkowicie niedopuszczalne i równoznaczne z ich fałszowaniem), a z drugiej poddaje zebrane świadectwo możliwie obiektywnej analizie. Dodatkowo podczas tworzenia źródła ustnego wywiązuje się często swoista kłótnia i niezrozumienie między badaczem a świadkiem: ten pierwszy, opierając się na innych źródłach historycznych, konstruuje pewną wizję przeszłości („przeczytałem o tym”), której świadek historii, opierając się na własnych przeżyciach („byłem tam”), może zaprzeczyć, mówiąc, że było inaczej. Kto ma rację, skoro słuszność jednego i drugiego podejścia trudno udowodnić?

Aby jeszcze bardziej skomplikować sytuację, można sięgnąć po inny, charakterystyczny zabieg: bezpośredniej konfrontacji świadka ze źródłami pisanymi. Próbowałem zrealizować to nieco prowokacyjne działanie w rozmowie z Edmundem Łebkiem, odwołując się do dokumentacji UB dotyczącej tragicznych wydarzeń z 1946 r. Były funkcjonariusz uniknął jednak polemiki i nie skomentował udokumentowanych informacji. Z kolei działacze NZS, którym pokazywaliśmy raporty MSW związane z ich działalnością, na ogół nie traktowali ich zbyt poważnie, zwracając uwagę na płytkość i ograniczoną wiedzę służb na temat działań opozycyjnych. Czy była to tylko poza, czy rzeczywiste przekonanie? Czy wierzyć materiałom SB, sugerującym niekiedy skuteczne infiltrowanie inicjatyw opozycyjnych, czy pamięci świadków, którzy z reguły twierdzą coś przeciwnego? Pytania te pozostają otwarte. Zapewne jedyną rozsądną odpowiedzią jest żmudne analizowanie każdego konkretnego przypadku z osobna.

Dodatkową, wartą rozważenia jest kwestia specyficznego subiektywizmu oraz względy etyczno-moralne towarzyszące prowadzonemu wywiadowi. Historyk musi bowiem w pewnym momencie zastanowić się nad podstawową, acz drażliwą kwestią: czy osoba, z którą prowadzi wywiad, mówi prawdę czy kłamie? A jeżeli się myli, to czy czyni to dobrowolnie czy nieświadomie? Należy przy tym dopowiedzieć, że nawet nieprawdziwe informacje podawane przez świadka są pożyteczne dla historyka w analizie pamięci o przeszłości. Wspomnienia nie stanowią wyraźnego obrazu przeszłych zdarzeń, ale pozwalają zbadać konstruowanie 
przeszłości przez jej uczestnika: praca historyka łączy się tu z warsztatem socjologa i psychologa.

Sam badacz nie jest zresztą osobą pozbawioną własnych poglądów, odczuć, wizji przeszłości. Dążąc do obiektywizmu, nie może całkowicie wyzwolić się z tych uwarunkowań. Mit historyka, który na wzór eksperymentów z laboratoriów badawczych z dziedziny nauk ścisłych beznamiętnie rekonstruuje przeszłość, umarł wraz z odejściem od dziewiętnastowiecznego pozytywizmu. Jednak świadomość własnych ograniczeń pozwala w dużej mierze je zneutralizować.

Odczułem to na własnej skórze z jednej strony przepytując działaczy opozycyjnych z lat 8o. XX w., a z drugiej rozmawiając z reprezentantem aparatu represji komunistycznego państwa. Dostrzegłem, że bezwiednie nabierałem dystansu do wypowiadanych przez funkcjonariusza UB słów i bardziej krytycznie oceniałem jego opowieść niż relacje zdecydowanie od niego młodszych i działających kiedyś w słusznej sprawie opozycjonistów. Tymczasem historyk nie powinien wartościować wspomnień świadka historii, ale zachować jak najbardziej neutralną postawę. Równie krytycznie, w znaczeniu krytyki naukowej, a nie poglądowej, musi podchodzić do każdego rozmówcy, choćby był to najgorszy przestępca czy też największy idol. Dystans i świadomość konieczności analizowania narracji świadka - niezależnie od tego, czy się z nim nie zgadzamy, czy pochwalamy jego poglądy i życiowe wybory - jest warunkiem koniecznym do stworzenia dokumentu historii mówionej. W innym wypadku wyprodukujemy publicystyczny wywiad. Nota bene wyczuwał to już niehistoryk Kazimierz Moczarski, który w ekstremalnych warunkach stalinowskiego więzienia zdobył się na rozmowy z Jürgenem Stroopem, katem warszawskiego getta ${ }^{2}$.

\section{Meandry pamięci}

Najbezpieczniej, ale może też zbyt asekurancko, można stwierdzić, że dzięki źródłom ustnym historyk ma szansę analizować nie tyle same wydarzenia, ile pamięć o nich. Osoba, z którą rozmawia historyk, jest przecież nie tylko świadkiem historii, lecz także dającym świadectwo: sam fakt opowiadania narzuca pewną subiektywną interpretację i ingerencję w przeszłość. Pozostaje otwartą kwestią, w jakim stopniu owa pamięć przystaje do przeszłej

24 K. Moczarski, Rozmowy z katem, Warszawa 1977 (oficjalna, nieocenzurowana wersja ukazała się w Polsce dopiero w 1992 r.). 
rzeczywistości. Idąc postmodernistycznym tropem, można by powiedzieć, że pamięć nie odtwarza przeszłości, lecz ją obrazuje. Niemniej trzeba podkreślić, że jest to obraz prawdziwej, a nie zmyślonej przeszłości - pójście śladami ponowoczesności wydawałoby mi się jednak zbyt naiwne i intelektualnie nieciekawe. Pamięć jest więc dla mnie kompatybilna z prawdą w jej arystotelesowskim ujęciu.

Nie zmienia to faktu, że świadek mówi - tu i teraz - o tym, co było wcześniej. Nie da się zatem uniknąć fatalistycznego umieszczenia świadectwa w teraźniejszości, a opowieści o wydarzeniach w przeszłości. Różnica perspektyw czasowych powoduje, że przepytywana osoba nie pokazuje nam przeszłości w sposób dosłowny, lecz opowiada o niej; nie świadczy o minionych wydarzeniach, lecz o swojej pamięci tych wydarzeń ${ }^{25}$.

W związku z tym w analizie świadectwa powinno się brać pod uwagę psychologiczną wiedzę o ludzkiej pamięci i zapytać, czy świadek pamięta wszystko i czy pamięta naprawdę to, co było. Nieraz zdarzało się, że ofiara Holocaustu była przekonana, że przebywała w obozie koncentracyjnym tuż obok komór gazowych, podczas gdy badania terenowe wykazywały, że opisywany barak znajdował się parę kilometrów od miejsca kaźni. Zinternalizowany strach i wywołana nim trauma znacznie skróciły ten dystans w pamięci. Ponadto badacze świadectw osób, które przeżyły Shoah, stwierdzili np., że po premierze filmu fabularnego Lista Schindlera wielu świadków ówczesnych wydarzeń nieświadomie lokalizowało swoje wspomnienia w scenerii prosto z planu filmowego. Świadek widzi, słyszy, odczuwa, myśli i odbiera otaczający go świat w nieustannie odnawiającej się teraźniejszości, co mimowolnie wpływa na konstruowanie obrazu własnej przeszłości i wspomnień.

25 Problem relacji między pamięcią a historią jest tematem coraz większej liczby francuskich opracowań. Zob. np.: La mémoire, entre histoire et politique, „Cahiers français”, nr 303 (2001) (temat przewodni numeru); J.C. Martin, La mémoire, l'histoire et l'oubli. Pour un autre régime d'historicité, "Revue d'histoire moderne et contemporaine”, nr 47 (4/200o), s. 783-804; P. Garcia, Les lieux de mémoire, une poétique de la mémoire?, „Espace/Temps”, nr 74/75 (2000), s. 122-142; Les historiens et le travail de mémoire, „Esprit”, t. 8-9 (2000) (temat przewodni numeru); Travail de mémoire 1914-1998, „Autrement”, nr 54 (1999) (temat przewodni numeru); Mémoire, histoire, „Revue de métaphysique et de morale", nr 1 (1998) (temat przewodni numeru); H. Rousso, La hantise du passé, Paris 1998; M.C. Lavabre, Usages du passé, usages de la mémoire, „Revue française de science politique”, nr 3 (1994); a także: Les lieux de mémoire..., t. 1-3. 
Niekiedy językiem późniejszych opracowań i doświadczeń przemawiali również byli działacze warszawskiego NZS, z którymi rozmawiałem. Jednak najwyraźniejsze elementy psychologii pamięci ujawniły się w trudnej rozmowie z Edmundem Łebkiem. W kluczowym wątku morderstwa z 1946 r. doświadczyłem częstego w relacjach ustnych zjawiska wyparcia trudnych faktów ze świadomości, czy też niechęci dzielenia się intymnymi szczegółami życia z obcą osobą, jakim jest dla świadka historii historyk. Od momentu opowieści o powrocie do Polski tuż po zakończeniu II wojny światowej pamięć Łebka przestała być nagle szczegółowa. Świadek zaczął wypowiadać się zwięźle, zdawkowo, nie dając się wciągnąć w głębsze rozważania. Wyjaśnienie okoliczności zabójstwa z 1946 r. okazało się zdumiewająco lakoniczne: Łebek stwierdził, że wzmiankowany agent „Fred” był co prawda wykorzystywany przez kontrwywiad jako informator, ale w istocie był kolaborantem niemieckim i miał trafić do więzienia. Podjął próbę ucieczki i z tego powodu został zastrzelony. Rozmówca starał się ująć opowieść o tej sprawie w bezosobowe ramy. Tylko tyle - temat został ucięty.

Łebek nie skomentował delikatnego nawiązania przeze mnie do trudnego i traumatycznego wątku jego późniejszego załamania psychicznego i prób samobójczych. Nie udało mi się nawet zweryfikować zawartych w dokumentach informacji, czy rzeczywiście owo załamanie i próby samobójcze miały miejsce. Czy milczenie świadka jest uzasadnione? Oczywiście. W perspektywie badawczej przynosi ono rozczarowanie, ale z czysto ludzkiej perspektywy, nie może budzić zdziwienia. Sytuacja w tym konkretnym przypadku była o tyle specyficzna, że przecież pierwotnym impulsem do rozmowy była reakcja Łebka na mój artykuł w „Przeglądzie Archiwalnym”, który skłonił go do przedstawienia własnej wersji wydarzeń. Ostatecznie świadek mówił o wielu pobocznych sprawach i w niewielkim stopniu odniósł się do interesujących mnie zdarzeń. Odczuwał potrzebę opowiedzenia o innych, mniej kontrowersyjnych wątkach - chciał podzielić się historią swojego życia.

Trzeba bardzo uważać, aby nie przekroczyć trudno dostrzegalnej granicy, którą - zupełnie nienaukowo - należałoby określić jako granicę przyzwoitości. Jednocześnie niezwykle niebezpieczne jest narzucanie świadkowi konkretnych odpowiedzi i wyjaśnień, gdy nie chce on lub nie może samodzielnie sformułować własnej narracji. W psychologii sądowej nierzadko mamy do czynienia z przypadkami, w których zastosowanie odpowiedniej sugestii może np. spowodować wmówienie świadkom określonego biegu wydarzeń i zadecydować o kształcie zeznań. Pamięć absorbuje rzeczywistość i ulega zewnętrznym wpływom. 
Wszystko to wskazuje na znaczne ograniczenia ludzkiej pamięci. Dodatkowo, świadome działanie świadka, który z premedytacją przedstawia historykowi swoją wersję wydarzeń, przemilcza pewne informacje, modyfikuje lub zmyśla inne, decyduje o ostatecznym kształcie świadectwa. Nie można jednak demonizować tego zjawiska. Po pierwsze, solidna wiedza o epoce, o której opowiada świadek, pozwala na wyeliminowanie ewidentnych kłamstw. Po drugie zaś, jeżeli owe nieścisłości czy kłamstwa są nieświadome, stanowią świetny materiał do badania mentalności, psychologii pamięci o przeszłości i obrazu danego wydarzenia we wspomnieniach jego uczestników.

Nie zmienia to faktu, choć może zabrzmi to brutalnie i w przejaskrawiony sposób, zawsze trzeba zakładać, że świadek kłamie, a historyk powinien starać się weryfikować i poddawać krytyce warsztatowej każdą informację, pogląd, opinię czy odczucie, którymi dzieli się świadek. Nie po to, by je odrzucić czy nawet uznać za fałszywe, ale by móc je właściwie odwzorować na metodologicznej mapie rekonstruowanej przeszłości.

Innym problemem z pogranicza psychologii i manipulacji, napotykanym podczas wywiadów, jest stosowanie przez świadka historii zaimków osobowych: „ja” i „my”. Niekiedy używa on liczby mnogiej, w innych momentach mówi w pierwszej osobie liczby pojedynczej. Zjawisko to ujawniło się zwłaszcza podczas wywiadów przeprowadzanych z działaczami warszawskiego NZS. Większość z nich używała słów: „zrobiliśmy”, „zorganizowaliśmy”, "drukowaliśmy”, „kolportowaliśmy”, „protestowaliśmy”, czasem bez wyraźnej prawidłowości opowiadając o wydarzeniach w liczbie pojedynczej. Czy umieszczanie się w grupie oznacza, że inni uczestniczyli w ten sam sposób w relacjonowanych wydarzeniach? Kim jednak ci „inni” byli? Czy liczba mnoga oznacza masowość zjawiska, czy po prostu swoisty pluralis maiestatis? Czy z kolei stosowanie zaimka „ja” świadczy o wyjątkowości przeżyć? Wraz z Robertem Spałkiem staraliśmy się ingerować w przypadkach, gdy narracja świadków ześlizgiwała się w kierunku „my” i dopytywać, kogo konkretnie dany świadek ma na myśli. Nierzadko okazywało się, że rozmówca albo nie był w stanie odtworzyć owej grupy, albo przybierał perspektywę wydarzeń z punktu widzenia „ja”. Trzeba jednak dodać, że niekiedy otrzymywaliśmy konkretne doprecyzowanie i wyjaśnienie.

Można zatem wyróżnić dwa psychologiczne mechanizmy stosowania liczby mnogiej w indywidualnych relacjach związane z przeciwnymi motywacjami. Po pierwsze, „my” może oznaczać świadomą lub bezwiedną chęć dowartościowania swojej osoby, podniesienia rangi, zwiększenia 
roli - w rodzaju „myśmy obalili komunizm”. Po drugie, „my” (ewentualnie $\mathrm{w}$ formie bezosobowej) stosują niekiedy osoby pragnące ukryć swoją rolę, rozmyć działania w szerszej perspektywie. Może to wynikać ze skromności, wstydu lub stanowić po prostu o charakterze narracji. Ten drugi mechanizm uwidocznił się również w relacji Edmunda Łebka. Oczywiście nierzadko użycie tej formy jest merytorycznie uzasadnione - wtedy, gdy świadek rzeczywiście ma na myśli konkretną grupę osób, która, zgodnie z jego pamięcią, czegoś dokonała i potrafi ją zdefiniować.

Jest bardzo charakterystyczne, że zwykle nie opowiada się o wydarzeniach i sprawach oczywistych. Tak też może postępować nasz świadek, który nie przekazuje historykowi informacji będących dla niego tak silnym elementem opisywanej rzeczywistości, że nie przychodzi mu nawet na myśl, by o nich wspomnieć. To bardzo poważne ograniczenie świadectwa ustnego. Jak podkreśla Pierre Bourdieu, być może zbyt przesadnie, osoba wspominająca, „która żyje w oczywistości opisywanego przez siebie świata społecznego, pomija milczeniem sprawy najważniejsze, ponieważ za bardzo je zna"26.

Dla działaczy warszawskiego NZS metody konspirowania, przebieg dyskusji, organizacyjne zaplecze protestów czy happeningów, ale też np. motywy działań czy elementy rzeczywistości materialnej schyłkowego PRL, były nierzadko czymś oczywistym, samoistnie zrozumiałym. Kiedy pytaliśmy np. o techniczną stronę drukowania materiałów drugoobiegowych czy wątki z dziedziny życia codziennego - reagowali zdziwieniem. Wydobywanie z rozmówców swoistych oczywistości ukazywało m.in. zmiksowanie życia studenckiego, towarzyskiego, imprezowo-zabawowego i polityczno-konspiracyjnego, uświadamiając nam, historykom, że mechaniczne i schematyczne rozdzielanie tych wszystkich sfer, choć wygodne dla uporządkowania analizy, często kłóci się z doświadczeniem świadków epoki.

W przypadku Edmunda Łebka pomijanie oczywistości nabiera - o ile nie zawodzi mnie intuicja - bardzo specyficznego charakteru. W czasie rozmowy odniosłem wrażenie, że dla niego czymś oczywistym było... zastrzelenie agenta „Freda”. Nie chodzi jednak o przyznanie się przez rozmówcę, że był nieludzkim mordercą, lecz o jego prostą dedukcję - skoro ten nazistowski kolaborant próbował uciec, to należało temu przeszkodzić - i koniec. Decyzja była szybka i spontaniczna. Niepotwierdzone przez 
świadka załamanie psychiczne sugeruje ponadto, że młody funkcjonariusz ciężko odchorował tę instynktowną reakcję z przeszłości. Moje wnioski mogą być jednak zbyt daleko idące. Zapewne lepszym wytłumaczeniem dla przemilczeń świadka historii jest wskazany wyżej psychologiczny mechanizm wyparcia ${ }^{27}$.

W związku z przytoczonymi w artykule wątpliwościami najlepiej przyjąć założenie, że świadek historii nie jest medium, łącznikiem z przeszłością odsłaniającym jej prawdę. Jego słowa to tylko i aż tylko opowiadanie, opisywanie własnego doświadczenia, ograniczone w dodatku do ram własnej pamięci i pytań badacza. To dopiero historyk, w swoich badaniach konstruujących naukową wizję przeszłości, może ocenić świadectwo jako prawdopodobne lub nie, przez stosowanie warsztatu historycznego, a także psychologicznego.

Czy wobec tego możemy już odpowiedzieć na postawione wcześniej pytanie kto ma rację historyk czy świadek? Moim zdaniem i jeden, i drugi może mówić prawdę, choć równocześnie ta odpowiedź nie wyklucza istnienia między nimi istotnych różnic. Świadek opowiada o swoim uczestnictwie w danym wydarzeniu, które było dla niego teraźniejszością: nie dostarcza więc on wiedzy historycznej, rozumianej jako wiedza o przeszłości, tylko wiedzę o minionej teraźniejszości, a może przytoczyć tylko swoje o niej wspomnienia i wyobrażenia. Z kolei historyk zajmuje się przeszłością sensu stricto. Opinie/analizy i jednego, i drugiego mogą być prawdziwe, choć odmienne, bo sytuujące się na dwóch różnych płaszczyznach: świadek przekazuje swoją prawdę o teraźniejszości, w której kiedyś uczestniczył, historyk zaś postrzega minioną teraźniejszość w naukowej systematyzacji przeszłości.

Owa systematyzacja niesie za sobą pewne pułapki: badaniom podlega tylko to, co przetrwało w pamięci czy też w formie artefaktów, dokumentów, wszystkich możliwych śladów przeszłości - cała reszta przepada. I tutaj właśnie możemy dostrzec wartość historii mówionej. Jak wspominałem na początku, źródła ustne pozwalają odtworzyć niezapisane obszary przeszłości czy też pamięci o niej - fragmenty przeszłych zdarzeń, których nie można zapisać lub które nie zostały zapisane.

27 Więcej na ten temat zob. m.in. w: N. Antoszewska, Mechanizmy obronne w ujęciu psychoanalitycznym, „Studia Erazmiańskie”, nr 5 (2010), s. 114-130; H.J. Grzegołowska-Klarkowska, Mechanizmy obronne osobowości, Warszawa 1986; J. Zinczuk-Żelazna, Mechanizm wyparcia - teoria i badania, „Postępy Psychiatrii i Neurologii”, nr 2 (2014), S. 117-123. 
Rozgraniczenie to nie jest bezpodstawne. Dwa człony definicji nie oznaczają tego samego. Jeśli chodzi o to, co niezapisywalne, zwróćmy uwagę tylko na jedno zjawisko: o niektórych rzeczach się nie pisze, bo się o nich mówi, myśli lub przeżywa w danej chwili. Trochę inaczej jest w przypadku tego, co mogło być, a nie zostało zapisane przeważnie z dwóch przyczyn. Po pierwsze, nie było możliwości zapisania, jak w przypadku analfabetów lub świadków zapomnianych przez historię, którzy nigdy nie byli obiektem zainteresowania tradycyjnych badaczy i nie mogli zaistnieć w klasycznych źródłach historycznych. Po drugie, z powodów związanych z sankcjami za spisywanie wspomnień związanych z uwarunkowanym politycznie wydarzeniem. Tak działo się np. w wypadku okupacji czy deportacji - świadectwo urastało wtedy do rangi aktu oporu. Dlatego też po II wojnie światowej wiele jej ofiar, które przeżyły, odczuwało nieodpartą potrzebę opowiadania o swoich losach, świadczenia o przeszłości, przekazywania zabronionej prawdy czy raczej konstruktu owej prawdy.

\section{Wywiady od kuchni}

Warto w tym kontekście powrócić raz jeszcze do kwestii współuczestniczenia historyka w tworzeniu źródła od technicznej strony prowadzenia wywiadu. Współuczestnictwo nie może być bowiem za duże, ponieważ to w końcu świadek ma mówić, nie badacz. Jak sugerowałem, ten ostatni nie powinien wykazywać zbyt daleko idącej empatii wobec opowiadającego - niezależnie od tego, co sądzi o jego słowach i postępowaniu. Badacz nigdy nie będzie w stanie całkowicie odciąć się emocjonalnie od wysłuchiwanej historii, musi jednak zachować odpowiedni dystans, by móc poddać rejestrowane słowa naukowej interpretacji.

Na pewno głównym zadaniem badacza jest słuchanie - nie może się zbytnio narzucać. Świadkowi należy pozwolić się wysłowić, pozwolić mu mówić. Dlatego też nie przerywałem długich i nieco nieskładnych monologów Edmunda Łebka, skaczącego z tematu na temat, czy też licznych dygresji, w które zapędzali się byli działacze warszawskiego NZS. Stworzenie pewnego rodzaju mapy myśli, możliwe przy zapewnieniu świadkowi swobody wypowiedzi, pozwala lepiej zrozumieć jego sposób postrzegania przeszłości, wyczuć stosowane konstrukcje myślowe, pojęciowe, rozumienie świata, wniknąć w meandry pamięci.

Zarazem jednak współuczestniczenie historyka w nagrywanym wywiadzie nie może być zbyt małe. W końcu to jego pytania i podpowiedzi umieszczają opowieść świadka w odpowiednim kontekście. Rodzaj pytań 
wpływa na jakość i wartość całego wywiadu. Dlatego trzeba przyłożyć dużą wagę do właściwego doboru poruszanych w rozmowie zagadnień, opartych na wyczerpującej wiedzy na temat świadka historii i okresu, który podlega badaniu. Faktem jest, że nawet najlepiej skonstruowany plan rozmowy i tak ostatecznie zależy w dużej mierze od rozmówcy. Edmund Łebek opowiadał wiele o swojej młodości, pobycie we Francji, a zwłaszcza o czasach wojennych, ucieczkach z niemieckich obozów, komunistycznej konspiracji. Nie chcąc za bardzo ingerować w potoczystą wypowiedź świadka, próbowałem go delikatnie nakierowywać na kluczową sprawę trzech strzałów z 1946 r. i agenta „Freda”, a także jego złego stanu psychicznego z tego okresu. On jednak uparcie powracał do o wiele dla siebie przyjemniejszych, a przynajmniej wygodniejszych wspomnień z lat wcześniejszych.

Ponadto kwestionariusz pytań nie może być sztywny choćbyśmy nawet rozmawiali ze świadkami reprezentującymi to samo środowisko. Pytania powinny być także dostosowywane do faktycznego przebiegu rozmowy i indywidualnych cech każdego opowiadającego, jego biografii i roli w analizowanych wydarzeniach. Nie można także zapomnieć o wpływie na kształt opowieści świadka historii ról pełnionych przez niego dzisiaj. W przypadku działaczy warszawskiego NZS rozmawialiśmy z osobami, które czynnie wspierają obecny obóz władzy. Inne popierają opozycję, a jeszcze inne zachowują dystans do polityki. Funkcjonowanie świadków po różnych stronach politycznej, ideologicznej czy światopoglądowej barykady, siłą rzeczy stanowi problem dla historyka. To zresztą fenomen dawnej opozycji antykomunistycznej: wspólny wróg. „Czerwone” państwo komunistyczne jednoczyło bardzo różne osobowości. W naturalny sposób ich drogi często rozchodziły się po 1989 r. Przygotowując się do wywiadu, historyk musi być świadomy tej sytuacji.

Pytania nie powinny ponadto powielać faktografii z podręczników, książek historycznych czy spisanych wspomnień naszego rozmówcy. Nie można oczywiście zapomnieć o faktach: świadkowie historii często uzupełniają, uszczegóławiają, przedstawiają nowe interpretacje i konteksty wydarzeń historycznych. Faktografia to jednak tylko baza - równie ważne, a z pewnością ciekawsze, są wątki dotyczące odczuć świadka, jego subiektywnej, indywidualnej oceny wydarzeń. Największym błędem w prowadzonym wywiadzie jest pozwolenie rozmówcy na prowadzenie podręcznikowego wykładu historii na temat epoki. W takiej sytuacji należy podjać próbę skierowania opowieści na indywidualne i subiektywne tory. Obiektywizacji może dokonać dopiero historyk. 
O jakości źródła ustnego decyduje również po części dobór świadków. Często taka swoista selekcja sprowadza się do jednego, trochę okrutnego kryterium wieku uczestnika danych wydarzeń. Z oczywistych względów w pierwszej kolejności wypada spotkać się z najstarszymi świadkami historii. Natomiast w dalszej kolejności najlepiej byłoby przygotować przemyślaną listę osób, opierając się na informacjach wyłuskanych z ich biografii. Tak starałem się uczynić wraz z Robertem Spałkiem, kiedy przygotowywaliśmy się do wywiadów z działaczami NZS.

Pozostaje również wątpliwość, czy należy „przepytywać” jedynie czynnych aktorów analizowanego wycinka przeszłości, czy też biernych lub drugoplanowych świadków. Z pewnością świadectwa jednych i drugich mogą być interesujące, podobnie jak wypowiedzi „świadków z drugiej ręki”, czyli rodziny świadka historii, jego znajomych, kolegów. Najlepiej po prostu łączyć różne kategorie.

Nie można także zapominać, że rozmowa prowadzona jest w specyficznych warunkach. Świadek często opowiada nam historię swojego życia w obcym dla siebie miejscu, patrzy na wycelowany w niego dyktafon czy kamerę i musi zwierzać się z często osobistych spraw przed przeważnie nieznaną sobie osobą. Wytwarza się zatem swoista sytuacja społeczna, która implikuje autodefinicję świadka względem pytającego badacza i otoczenia. Ta postawa z reguły różni się od sytuacji, w której nasz świadek historii przebywa sam na sam ze swoimi myślami.

Na tym polu moje zadanie było szczególnie utrudnione, ponieważ pracuję w Instytucie Pamięci Narodowej - instytucji o wiele bardziej związanej z bieżącą debatą polityczną niż uczelnie akademickie czy instytuty Polskiej Akademii Nauk. Wiąże się to m.in. z faktem, że IPN łączy w sobie funkcje badawcze, edukacyjne, archiwalne, ale też prokuratorskie czy lustracyjne. Dla jednych „funkcjonariusze IPN” realizują politykę historyczną na polecenie władz, dla innych są „żołnierzami prawdy”. Pomiędzy tymi skrajnościami nie pozostaje wiele miejsca na niezaangażowane interpretowanie działań Instytutu ${ }^{28}$.

To umocowanie instytucjonalne miało szczególnie duże znaczenie w obu wybranych przeze mnie przykładach. Jak już sugerowałem, wielu działaczy warszawskiego NZS, z którymi rozmawialiśmy, to dzisiaj poli-

28 Por.: P. Pleskot, Delicate Polish Mission: The Institute of National Remembrance (IPN) in Poland, „Central European Political Science Review”, nr 55 (2014), s. 19-28. 
tycy/sympatycy konkurujących ze sobą partii, które w swoich programach

formułują konkretne postulaty wobec IPN: od chęci jego zamknięcia, po zwiększenie budżetu. Co więcej, funkcjonowanie Instytutu jest związane z debatą wokół lustracji i spuścizny Służby Bezpieczeństwa, w tym inwigilacją i penetracją opozycji. Dla niektórych historyk IPN kojarzy się z badaczem zaangażowanym w tzw. „dziką lustrację”, tropiącym tylko tajnych współpracowników służb. Kontekst ten powodował, przynajmniej początkowo i w niektórych przypadkach, dodatkowe dystansowanie się naszych rozmówców.

Siłą rzeczy te czynniki odegrały sporą rolę również w przypadku spotkań z Edmundem Łebkiem. Przecież impulsem do rozmowy stał się artykuł bardzo krytycznie oceniający działania komunistycznego aparatu represji, oparty na materiałach UB i opublikowany w periodyku IPN: „Przegląd Archiwalny”. Punktem wyjścia rozmowy była więc chęć wytłumaczenia się dawnego funkcjonariusza przed funkcjonariuszem IPN - to sytuacja jednak bardzo rzadko spotykana, bowiem najczęściej dawni pracownicy resortów siłowych unikają spotkań z badaczami, których uznają za wrogich im rewizjonistów historycznych. Nastawienie to nie może zresztą dziwić, skoro pion prokuratorski IPN regularnie próbuje stawiać byłych UB-eków i SB-eków przed sądami. W przypadku Łebka okolicznością łagodzącą i zmniejszającą dystans czy wpływającą na niecodzienność sytuacji był fakt, że rozmawialiśmy u niego w domu, w którym mógł poczuć się bardziej komfortowo i bezpiecznie niż w miejscu publicznym czy w przestrzeni biurowej. Jak się jednak okazało, nie wystarczyło to do złamania pewnej bariery i pełnego, a przynajmniej satysfakcjonującego badawczo, zrealizowania pierwotnego zamiaru wytłumaczenia okoliczności zabójstwa z 1946 r.

Na koniec należy stwierdzić, że wykorzystaniu źródeł ustnych, a także warsztatowi historyka tymi źródłami się zajmującego, nie towarzyszą obecnie żadne sztywne dogmaty i schematy. Badania z wykorzystaniem metody historii mówionej w dużej mierze polegają na improwizacji i intuicji - co nie zmienia faktu, że muszą być oparte na metodologicznej partyturze.

Źródła ustne, podobnie jak każde inne, niosą ze sobą tyle możliwości, co zagrożeń. Na pewno należy traktować ten rodzaj materiału historycznego bez uprzedzeń, czyli tak, jak pozostałe ślady przeszłości, wyróżniające 
154 się tylko dłuższą metryką. I to właśnie o taką swoistą normalizację chodzi, a nie o postawienie historii mówionej na piedestale. Jest ona tylko i aż jedną z możliwości interpretowania przeszłości. Niech więc będzie traktowana na równi z innymi, a to już wystarczy. 
Antoszewska N., Mechanizmy obronne w ujęciu psychoanalitycznym, „Studia Erazmiańskie”, nr 5 (2010), s. 114-130.

Bédarida F., L'historien, régisseur du temps? Savoir et responsabilité, „Revue historique”, nr 605 (1/1998), s. 3-24.

Bédarida F., Le mémoire contre l'histoire, „Esprit”, nr 7 (1993), s. 7-13.

Bourdieu P., Sur les rapports entre la sociologie et l'histoire en Allemagne et en France. Entretien avec Lutz Raphael, „Actes de la recherche en Sciences Sociales”, nr 106-107 (1995), s. 108-122.

Garcia P., Les lieux de mémoire, une poétique de la mémoire?, „Espace/Temps”, nr 74/75 (2000), s. $108-122$.

Ginzburg C., Poni C., La micro-histoire, „Le Débat. Histoire, politique, société”, t. 17 (1981), s. $133-136$.

Grzegołowska-Klarkowska H.J., Mechanizmy obronne osobowości, Warszawa 1986.

Hartog F., Régimes d'historicité. Présentisme et expériences du temps, Paris 2003.

Joutard P., Historiens, à vos micros! Le document oral, une nouvelle source pour l'histoire, „L'Histoire”, t. 12 (1979), s. 106-120.

Joutard P., Orale (histoire), [w:] Dictionnaire des sciences historiques, red. A. Burguière, Paris 1986.

Kurkowska-Budzan M., Antykomunistyczne podziemie zbrojne na Białostocczyźnie. Analiza wspótczesnej symbolizacji przeszłości, Kraków 2009.

Kurkowska-Budzan M., Historia zwyktych ludzi. Wspótczesna angielska historiografia dziejów społecznych, Kraków 2003.

La mémoire, entre histoire et politique, „Cahiers français”, nr 303 (2001).

Lavabre M.C., Usages du passé, usages de la mémoire, „Revue française de science politique”, nr 3 (1994), s. 480-493.

Les historiens et le travail de mémoire, „Esprit”, t. 8-9 (2000).

Les lieux de mémoire, red. P. Nora, t. 1-7, Paris 1984-1992.

Martin J.C., La mémoire, l'histoire et l'oubli. Pour un autre régime d'historicité, „Revue d'histoire moderne et contemporaine", $\mathrm{nr} 47$ (4/20oo), s. 783-804.

Mémoire, histoire, „Revue de métaphysique et de morale”, nr 1 (1998).

Moczarski K., Rozmowy z katem, Warszawa 1977.

Noiriel G., Penser avec, penser contre. Itinéraire d'un historien, Paris 2003.

Noiriel G., Qu'est-ce que l'histoire contemporaine?, Paris 1998.

Noiriel G., Sur la crise de l'histoire, Paris 1996.

Essais d'ego-histoire, red. P. Nora, Paris 1987.

Park R.E., Burgess E.W., Introduction to the Science of Sociology, Chicago 1921. 
Park R.E., Burgess E.W., McKenzie R., The City, Chicago 1925.

Pleskot P., Delicate Polish Mission: The Institute of National Remembrance (IPN) in Poland, "Central European Political Science Review”, nr 55 (2014), s. 19-28.

Pleskot P., W butach esbeka. Kilka refleksji na temat konfliktu emic-ethic w badaniach nad aparatem bezpieczeństwa PRL, [w:] Aparat bezpieczeństwa w perspektywie antropologii władzy $i$ antropologii organizacji, red. J. Syrnyk, Wrocław 2020 (w przygotowaniu).

Pleskot P., Intelektualni sasiedzi. Kontakty polskich historyków z francuskim środowiskiem „Annales" w latach 1945-1989, Warszawa 2010.

Pleskot P., Zbrodnia i kara w MBP. Sprawa Edmunda Łebka, „Przegląd Archiwalny”, t. 2 (2009), s. 325-334.

Pleskot P., Spałek R., Pokolenie 82-9o. Niezależne Zrzeszenie Studentów na Uniwersytecie Warszawskim we wspomnieniach (1982-1990), Warszawa 2011.

Pomian K., Historia. Nauka wobec pamięci, Lublin 2006.

Rousso H., La hantise du passé, Paris 1998.

Stolarz A., Dzielenie się pamięcią. Praktyka i teoria historii mówionej, Lublin 2016.

Thompson P.R., Voice of the Past: Oral History, New York 1978.

Travail de mémoire 1914-1998, „Autrement”, nr 54 (1999), ss. 272.

Wieś polska 1939-1948. Materiały konkursowe, oprac. K. Kersten, T. Szarota, Warszawa 1967-1971.

Zinczuk-Żelazna J., Mechanizm wyparcia - teoria i badania, „Postępy Psychiatrii i Neurologii”, nr 2 (2014), s. 117-123. 
The start point of the article are two of the author's experiences with oral sources - of completely different provenances. The first represented in total several dozen hours of recordings of the narratives of a dozen or so opposition activists: members of the underground Independent Students' Association at Warsaw University in the years 1982-1989. In turn, the second was an unexpected "confession" of someone from the other side of the barricades: Edmund Lebek, an officer of the Security Services from as far back as the 1940s, who had a human life on his conscience. Using these examples, the author provides a number of insights connected with the application of oral history in research into the recent history of Polish politics. The confluence of concrete research work and the methodology of oral history allows the researcher to achieve the advantages and dangers connected with the application of this type of source.

Keywords: oral history, Independent Students' Association, Security Services, methodology of history
Patryk

Pleskot

Oral history in research into the most recent political history - a few reflections (on two examples) 